\begin{tabular}{|c|c|}
\hline \multirow{3}{*}{ 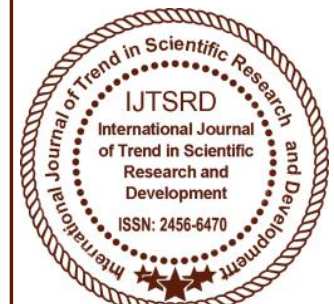 } & $\begin{array}{l}\text { International Journal of Trend in Scientific } \\
\text { Research and Development (IJTSRD) }\end{array}$ \\
\hline & International Open Access Journal \\
\hline & ISSN No: 2456 - 6470 | www.ijtsrd.com | Volume - 2 | Issue - 4 \\
\hline
\end{tabular}

\title{
Analysis and Design of Shear Wall with Various Openings Criteria
}

\author{
${ }^{1}$ D. W. Gawatre, ${ }^{2}$ T. S. Joshi, ${ }^{3}$ M. S. Kukade, \\ ${ }^{4}$ P. S. Kurumkar, ${ }^{5}$ V. R. Kale, ${ }^{6}$ Ms. A. R. Bodake \\ ${ }^{1}$ Faculty of Civil Engineering Department, ${ }^{2,3,4,5,6}$ Student
}

1,2,3,4,5,6Sinhgad Academy of Engineering, Savitribai Phule Pune University, Pune, Maharashtra, India

\begin{abstract}
Shear wall in a building construction, a rigid vertical diaphragm capable of transferring lateral forces from exterior wall, floors and roofs to the ground foundation in a direction parallel to their planes . Example, reinforced concrete wall. Wind and seismic loads are the most common load that shear wall are designed to carry. In this project we are going to study about shear wall and its various openings . According to the previously studied papers, shear wall having different kind of opening shows different behavior .Variation in the opening can be of its size, percentage of opening with respect to size of wall, its shape and location. The variation regarding shear wall will be its thickness. We are also going to study parameter such as seismic loads, storey drift, storey displacement, lateral stiffness. .After considering all these parameters with respect to shear wall and its opening, the behavior of shear wall can be concluded.
\end{abstract}

Keywords - Shear wall openings, shape of openings , seismic loads ,ultimate strength, economy

\section{INTRODUCTION}

The shear wall is a structural element designed to resist lateral forces. If we take it on a structural point of view shear wall is structural member that transmit the lateral load as well as horizontal load. The main difference column and shear wall lies in its response to the load applied to it and its functionality. Generally it will be provided when the wind pressure and seismic force will be act on the structure. They are made upon in woods, concrete, CMU (Concrete masonry unit). Shear wall are the more stable structural systems. Because, their supporting area (total cross-sectional area of all shear walls) with reference to total plans area of building, is comparatively more, unlike in the case of RCC framed structures.

\section{Need of shear wall}

Shear walls are not only designed to resist gravity / vertical loads (due to its self-weight and other living / moving loads), but they are also designed for lateral loads of earthquakes / cyclones. The walls are structurally integrated with roofs / floors (diaphragms) and other lateral walls running across at right angles, thereby giving the three dimensional stability for the building structures. Shear wall structural systems are more stable. Because, their supporting area (total cross-sectional area of all shear walls) with reference to total plans area of building, is comparatively more, unlike in the case of RCC framed structures. Walls have to resist the uplift forces caused by the pull of the wind. Walls have to resist the shear forces that try to push the walls over. Walls have to resist the lateral force of the wind that tries to push the walls in and pull them away from the building Shear walls provide large strength and stiffness to buildings in the direction of their orientation, which significantly reduces lateral sway of the building and thereby reduces damage to structure and its contents. Since shear walls carry large horizontal earthquake forces, the overturning effects on them are large.

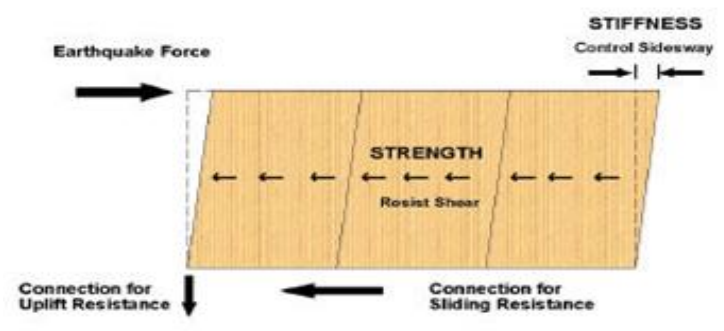

Figure 1: Function of shear wall 
Function of shear wall

1. It significantly reduces lateral displacement/story displacement/story drift.

2. Reduces the time period of vibration of the building.

3. Reduces moments and induced torsion during earthquakes.

4. Increases stiffness of the building

5. Strength and Stiffness

Forces acting on shear wall:

Shear walls resist two types of forces: shear forces and uplift forces. Connections to the structure above transfer horizontal forces to the shear wall. This transfer creates shear forces throughout the height of the wall between the top and bottom shear wall connections. The strength of the lumber, sheathing and fasteners must resist these shear forces or the wall will tear or "shear" apart Uplift forces exist on shear walls because the horizontal forces are applied to the top of the wall. These uplift forces try to lift up one end of the wall and push the other end down. In some cases, the uplift force is large enough to tip the wall over. Uplift forces are greater on tall short walls and less on low long walls. Bearing walls have less uplift than non-bearing walls because gravity loads on shear walls help them resist uplift. Shear walls need holdown devices at each end when the gravity loads cannot resist all of the uplift. The holdown device then provides the necessary uplift resistance.

\section{LOADS ACTING ON SHEAR WALL}

\section{A. Wind Load}

Wind load is really the result of wind pressures acting on the building surfaces during a wind event. This wind pressure is primarily a function of the wind speed because the pressure or load increases with the square of the wind velocity (i.e., doubling of wind speed results in a four-fold increase in wind load or pressure).

\section{B. Earthquake Load}

Earthquake forces experienced by a building result from ground motions (accelerations) which are also fluctuating or dynamic in nature, in fact they reverse direction somewhat chaotically.

\section{LITERATURE SURVEY}

\section{A. Effects of Openings in Shear Wall on Seismic Response of Structure by Vishal A. Itwar,Dr. Uttam B. Kalwane}

For parametric study 6 and 12 storied $7 \times 3$ bays apartment buildings with typical floor plan of $35 \mathrm{mx} 15 \mathrm{~m}$ and floor height of $3 \mathrm{~m}$ with different openings size and location in shear walls were modeled in STAAD pro. An equivalent static analysis for three dimensional models of the buildings was performed as per IS 1893 (part 1): 2002. Seismic responses of the analyzed structures were compared. From the results it is concluded that for opening area $<20 \%$ of shear wall area, the stiffness of shear-wall structure is more affected by the size of openings than their arrangement in the shear walls. However, for opening area $>20 \%$ of shear wall area, the stiffness of the system is significantly affected by the openings arrangement in shear walls. Effects of horizontal location of door openings of size $1 \mathrm{~m} \times 2.1 \mathrm{~m}$ can be neglected on the stiffness of the system. However, vertical location of window opening significantly affects the stiffness of the system.

\section{B. Study on Lateral Resistance Behaviour of High Rise Building with Shear Wall and Bracings by Karthick S, Udaya Kumar S, Geetha G}

Study on the structural aspects of an R.C building with $\mathrm{G}+32$ stories are to be considered for lateral forces using structural components such as R.C shear wall and bracings. Non-linear analysis was done in ETABS 9.7.4 to check the lateral force resistant behavior of components. By providing shear wall and bracing the lateral forces are resisted by the structural components which have increased stiffness, deformability and decreased drift. To reduce the effect of earthquake, reinforced concrete shear walls are used in buildings. Properly designed and detailed buildings with shear walls have shown very good performance in past earthquakes. In some regions, they are known as braced wall lines for this very reason. An effective wall of this type is stiff and strong. A stiff, strong wall, on the other hand, resists lateral forces while providing support. In multi-story structures, shear walls are critical, because in addition to preventing the failure of walls, they also support the multiple floors of the building, ensuring that they do not collapse as a result of lateral movement in an earthquake. Buildings are generally composed of vertical and horizontal structural elements. The vertical elements commonly used to transfer lateral 
forces to the ground are: 1) shear walls; 2) braced frames. They make the height of the concrete structures to be soared and act as major earthquake resisting members.

\section{Effect of Openings in Shear Wall by Swetha $K$, Akhil P}

The zigzag arrangement of openings in shear walls is to be applied in This study reveals that the time period, displacement, drift, base shear and the overall seismic response of the structure is affected by the location of openings in shear wall. practice, since it provides comparatively $4 \%$ better performance than other arrangement of opening. Shear wall with openings provided in zigzag manner exhibited $1.35 \%$ higher value of time period and storey acceleration when compared to shear wall with openings arranged in vertical and horizontal manner and approximately $3 \%$ higher value of time period and storey acceleration when compared to shear wall without opening.

D. Effect of placement and openings in shear wall on the displacement at various levels in a building subjected to earthquake loads by Pooja R. Gupta and A.M. Pande

Study effect of location and openings in shear wall on behavior of structural frames. Shear walls must be placed in both the directions as shear wall in one direction may result in increase in moment in the transverse direction. Shear wall at periphery is found to be beneficial from reduction in displacement point of view. Provision of additional shear walls above the optimum requirement may not be useful in restricting displacements; however it may results in higher cost and unwanted gravity forces. There is marginal reduction in lateral displacement if the shear walls are extended beyond plinth level up to foundation level. Careful analysis of structures is necessary, if shear wall is provided only at lift well as it may result in unnecessary increase of forces in various columns. With the increase in openings in shear wall lateral displacement increases to greater extent.

\section{E. Design of shear wall in seismic region by Varsha Patil,Devikrishna.P.M}

Review of relevant literature to bring out the background of shear wall. The research contribution which have a direct relevance are mentioned in greater detail. Some of the historical works which have contributed greatly to the understanding of the design of shear wall are also described. The available literature from books, codes and research papers gives proper designing, positioning and introducing the shear wall in building. A building is made more strong to resist earthquake. Even though there are many methods for dissipating earthquake energy, shear walls are observed to be simple, efficient, economical and long lasting.

\section{F. Effects of Openings in Shear Wall on Seismic Response of Structures by Sharmin Reza Chowdhury,M.A.Rahaman,M.J.Islam, A.K.Das}

This paper at attempt is made to apply the finite element modelling in analyzing and exploring the behavior of shear wall with opening under seismic load actions. This study is carried out on 6- story frame-shear wall buildings, using linear elastic analysis with the help of finite element software, ETABS under earthquake loads in equivalent static analysis With the application of finite element approach using software, ETABS this study reveals that stiffness as well as seismic responses of structures is affected by the size of the openings as well as their locations in shear wall. It is advisable to say that before introducing opening in shear wall proper analysis should be made. It is also concluded that more the area of opening more the displacements conceded by the building and this trend increases with increasing story level. Thickening wall around the door openings are more effective than that of window opening as far as displacement is concerned at top most story level.

\section{G. Design method of reinforced concrete shear wall using EBCS by Dr. Suresh Borra1,P.M.B.Rajkiran Nanduri2,Sk.Naga Raju3}

Dr.SureshBorra1,P.M.B.Rajkiran Nanduri2,Sk.Naga Raju3 The primary purpose of this paper is believed that structural engineers working in the analysis and design of high- rise buildings will be benefited from the design shear wall by using EBCS(Ethiopian building code standards): 2-1995 and EBCS:81995 codes and its results. With the preliminary sizes, an analysis is made to determine if design criteria are met. If not, an analysis of the modified structure is made to improve its agreement with the requirements, and the process is continued until a design is obtained within the limits of acceptability. Starting the process with the best possible selection of member's results in a rapid convergence of the iterative process to the desired solution. It is almost mandatory for the structural engineer to compare several designs before choosing the one most likely to be the best from the 
points of view of structural economy and how well it minimizes the premium required by the mechanical, electrical, and curtain wall systems.

\section{DISCUSSION}

\section{Stiffness/Rigidity Of Shear Wall}

The stiffness/rigidity of a shear wall in a given direction $(\mathrm{R} x$ or $\mathrm{R} y$ ) is defined as a force required per unit displacement in the given direction.

Reinforcement Details:

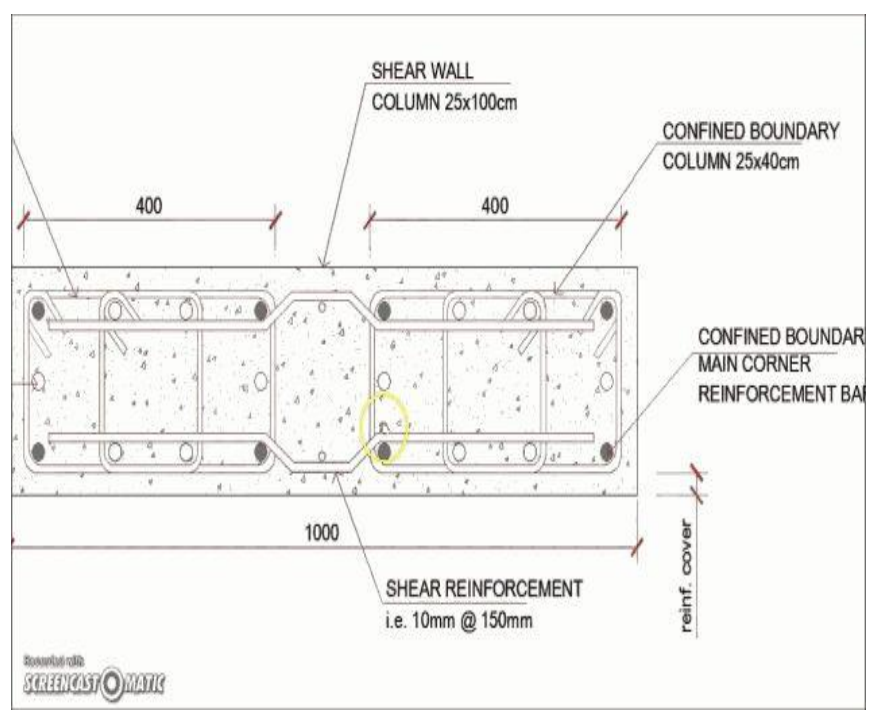

Types of shear wall:

1. Simply rectangular type and the flange walls

2. Coupled shear wall

3. Rigid frame shear wall

4. Column supported shear wall

5. Core type shear wall

Advantages of Shear Wall

1. Very good earthquake performance if properly designed

2. Easy to construct

3. Straight forward reinforcement details

4. Reduce construction of cost

Disadvantages

1. Require large moment connection

2. Films appearance

3. Loud banging sound associated with buckling of web plates

4. Low stiffness and energy dissipation capacity

5. Require large moment connections

\section{CONCLUSION}

- Now-a-days shear walls are highly preferable for high rise buildings. It is highly economical. It is better replacement of many columns in a single plane.

- As we are considering openings in shear wall, the results gives us adequate sizes of openings with minimum drift and minimum displacement.

- There are various methods for analysis and design of shear wall

a) Finite Element Analysis

b) Equivalent Frame Method

c) linear and non linear analysis

- Various Software are applicable for Finite Element Analysis Method

a) STAAD PRO

b) E-TABS

c) ANSYS

- Various openings criteria are used example:

a) position of shear wall

i) inner walls

ii) outer walls

iii) corners

b) sizes of openings

i) according to percentage of openings

c) shapes of openings

i) square

ii) rectangle

iii) circular

iv) trapezoidal

d) total number of openings

i) According to function of openings i.e. door or window or ventilator.

- Shape of Shear wall also can change / vary according to aesthetic point of view.

- Shear wall can be circular.

- There are various modifications occur in conventional shear wall to higher its strength. 
- Various tests can apply on shear wall in laboratory. e.g. Shaking table test.

- Shear wall reinforcement play vital role. Applying Reinforcement on sides of openings have a research scope.

\section{References}

Journal Papers:

[1] Vishal A. Itwar ,Dr. Uttam B. Kalwane, Effects of Openings in Shear Wall on Seismic Response of Structure, ISSN : 2248-9622, Vol. 5, Issue 7, ( Part - 1) July 2015, pp.41-45.

[2] Karthick S, Udaya Kumar S, Geetha G, Study on Lateral Resistance Behaviour of High Rise Building with Shear Wall and Bracings, The International Journal Of Science \&Technoledge (ISSN 2321 - 919X)

[3] Swetha K S1, Akhil P A2, Effect of Openings in Shear Wall, International Research Journal of Engineering and Technology (IRJET), Volume: 04 Issue: 05 | May -2017.

[4] 1Pooja R. Gupta and 2A.M. Pande Effect of placement and openings in shear wall on the displacement at various levels in a building subjected to earthquake loads, International Journal of Research in Engineering and Applied Sciences.

[5] VarshaPatil 1,Devikrishna.P.M 2 Design of shear wall in seismic region International Journal of Scientific \& Engineering Research, Volume 5, Issue 12, December-2014 ISSN 2229-5518.

[6] Sharmin Reza Chowdhury1, M.A.Rahaman, M.J.Islam 2,A.K.Das Effects of Openings in Shear Wall on Seismic Response of Structures International Journal of Computer Applications (0975 - 8887) Volume 59- No.1, December 2012.

[7] Dr.Suresh Borra1,P.M.B.Rajkiran Nanduri2, Sk.Naga Raju3 Design method of reinforced concrete shear wall using EBCS AJER E-ISSN : 2320-0847 p-ISSN : 2320-0936 VOL-4, Issue -3, pp- 31-43 www.ijer.org.

[8] IS 1893(part 1) : 2002, “ Criteria for earthquake resistant design of structures, part 1, general provisions and buildings ", Fifth revision, Bureau of Indian Standards, ManakBhavan, Bahadur Shah Zafar Marg, New Delhi 110002.
[9] IS : 875 (Part 2) - 1987 (Reaffirmed 2008), "Code of practice for design loads for buildings and structures. Part 2- Imposed load." 